\title{
THE IMPACT OF THE COVID-19 CRISIS ON THE ACTIVITIES OF THE MUNICIPALITIES IN THE REPUBLIC OF BULGARIA
}

\author{
N. Karatova* \\ Department of Regional Development, Faculty of Economics, Trakia University, \\ Stara Zagora, Bulgaria
}

\begin{abstract}
After the declaration of the state of emergency in the country, a significant human and financial resource in Bulgarian municipalities was mobilised in order to fully implement the prescriptions of health authorities and to establish an organization to ensure the safety of life and health of citizens. In addition, municipal administrations continued to carry out their normal activities and provide much of the usual public services. At the same time, the intensity of work in the various activities of the municipality has changed completely, leading to a complete restructuring of the expenditures in municipal budgets. Activities related to social services have suffered an extreme workload. Other activities in the fields of culture, sport, school and children's health, and the economy have been completely discontinued. Educational work has been thoroughly restructured. In this regard, and at the background of drastically reduced own revenues of municipalities compared to the period March - April 2019, an acute shortage of liquid resources in municipal budgets has emerged, which is now growing exponentially. The report will present in detail both the trends in municipal expenditures and the reasons for the reduction of own revenues and will outline proposals for implementing measures to address the liquidity problem of municipalities in a short and medium term perspective.
\end{abstract}

Key words: own revenues, municipal expenditures

\section{INTRODUCTION}

On March 11, 2020, the World Health Organization (WHO) (1) declared COVID-19 a pandemic. The virus has spread far beyond the initial expectations of experts, which is the reason for declaring a pandemic. WHO admits their serious concern about the speed and scale at which the new coronavirus has spread around the world, as well as the number of people infected.

In this regard, at the proposal of the Council of Ministers, the National Assembly of the Republic of Bulgaria has declared a state of emergency throughout the country (2) and instructed the Council of Ministers to take all necessary measures to manage the emergency situation related to the COVID-19 pandemic and in accordance with article 57, paragraph 3 of the Constitution of the Republic of Bulgaria.

\footnotetext{
*Correspondence to: Nadya Vasileva Karatova, PhD student, Department of Regional Development, Faculty of Economics, Trakia University, Stara Zagora, Bulgaria, e-mail: karatova@gmail.com
}

In a Communication by the European Commission of 19 March 2020 (3), the COVID-19 outbreak was identified as a severe public health emergency, with cases of infection in all Member States of the Union. It has also been associated with a serious shock to the world economy, and the EU economy in particular. This turmoil has affected the economy through various channels:

- Shock in supplies as a result of delivery chain disruption;

- Shock in demand caused by lower consumer demand due to social distancing, travel bans, quarantines and measures to restrict the movement of citizens outside their homes;

- Negative impact related to uncertainty about investment plans and income loss forecasts;

- Liquidity difficulties have emerged in enterprises, households, countries and institutions.

The situation was characterized by a high dose of uncertainty... 


\section{THE NEW TASKS OF THE MUNICIPALITIES}

The municipalities in the Republic of Bulgaria, immediately after detecting the first cases of infection with the new coronavirus, took a number of measures to protect the population and to limit the spread of the virus. At the local level, significant human and financial resources were mobilized in order to fully implement the prescriptions of the health authorities and to create an organization for the safety of life and health of people, without affecting the normal activities of municipal administrations.

Thus, new, non-specific tasks have emerged in the work of municipalities, mostly related to the introduced anti-epidemic measures. In a very short time and against the background of a shortage in the market of personal protective equipment and disinfectants, many municipalities have managed to provide personal protective equipment for all employees, with priority for those who work "on the frontline". Already in the first days of the state of emergency, many municipalities initiated emergency deliveries of disinfectants and took the necessary special measures to treat the open and closed public areas - public buildings, parks, pavements, and squares, whereas, in addition to chemicals, the authorities provided the necessary machines for the disinfection of open public spaces. In order to ensure social distance when serving citizens, most of the municipalities undertook urgent repairs of their citizen service centres and tax directorates, consisting of placing special barriers, closing counters, etc. In order to limit the contacts between employees, the municipal administrations had to work with reduced staff, as some of the employees, whose position could allow them, have worked remotely from home, and this has seriously disrupted the usual work rhythm, while the performance of current tasks in certain places, especially in small municipalities, was difficult.

A very large part of all implemented measures in the municipalities have been described in a special section "Municipal care" on the website of the National Association of Municipalities in the Republic of Bulgaria (NAMRB), where over 800 news reports from municipalities have been published on 150 pages (4).

Guided by their innate sense of solidarity, the municipalities assisted the bodies of the
KARATOVA N.

Regional Health Inspectorates and the police, both with limited capacity of resources, in carrying out their tasks on establishing and identifying the contacts of infected persons. In addition, the municipalities organized regular inspections for compliance with the orders of the Minister of Healthcare. This task has mobilized the use of huge human resources, imposed additional costs for fuels, stationery, telephones - funds that significantly exceed those planned in municipal budgets and in many places the reserves have melted quickly. The crisis situation brought to the agenda the provision of new social services - supporting the supply of basic food and medicines to quarantined people living alone and families throughout the municipality. The municipalities invested their human resources, fuel costs, personal protective equipment for social workers and drivers into the provision of social services. The funds that the municipalities invested until the provision of European funds for "Patronage Care" projects exceeded even the funds from the budget approved for home social patronage activities. The municipalities which have municipal hospitals on their territory provided them with urgent support for the implementation of unforeseen repairs for the reorganization of wards for the treatment of COVID-19, and provided resources for the purchase of personal protective equipment and additional disinfectants. Many fundraising campaigns were also organized to supply equipment to treat the infection.

The municipalities were also assigned to recruit and organize volunteers to work in a crisis situation. This necessitated the organization of situational and logistics centres and the provision of personal protective equipment for their staff.

The new organization of the farmer and cooperative markets also demanded the use of unforeseen expenses for security and observance of the established order, means for personal protection of the guards, and means for disinfection of the areas of the respective market three times a day.

For objective reasons, all these events and activities had not been planned in the drafting of municipal budgets. This necessitated an urgent update of municipal budgets, which was hampered by the impossibility of holding municipal council meetings. 
Despite the emergency situation, the municipalities in the Republic of Bulgaria continued to fulfil their traditional responsibilities and commitments - providing cleanliness and landscaping activities, providing a continuous regime of street lighting, social patronage, administrative and technical services. The implementation of investment projects with priority for those financed under the Operational Programmes continued, despite the delayed verification, which has retained the resources needed for other payments. Municipalities continued to seek effective solutions locally and upgrade opportunities for social support and for maintaining security and stability at the local level, and responded with great responsibility to each new task, in compliance with the instructions of the Minister of Health.

\section{MUNICIPAL ACTIVITIES THAT "ECONOMIZE" EXPENDITURES}

With the declaration of the state of emergency to limit social contacts in order to stem the spread of the virus, some municipal bodies have temporarily ceased their activities:

In the part of activities delegated by the state (determined, according to item 1 of Decision of the Council of Ministers № 208 of 16.04.2019) (5) - nurseries, kindergartens and schools; centres for personal development and other extracurricular activities for children and students; cultural institutes of regional importance - museums, libraries, galleries, community centres. For the period of the state of emergency, followed by the emergency epidemiological situation declared on 13 May, no subsistence costs have incurred, except for labour expenditures (mainly for used paid leave). In schools, the educational process did not stop, and for the first time, there has been a mass transition to distance learning. During this period the subsistence costs for these activities have decreased, yet before the beginning of the workday, anti-epidemic measures had to be applied in the buildings, all premises disinfected, and personal protective equipment provided to all staff, as well as funds for all disinfection measures. At this stage, it is difficult to predict the amount of "economized" funds and whether it will ultimately be necessary to co-finance the activities delegated by the state to provide special funds to prevent infection with the new coronavirus.

Each month all funds allocated for the activities delegated by the state from the municipal budgets upon receipt of the total subsidy for delegated activities were regularly transferred to the accounts of the respective budget managers, however, the municipality could not operate them because they were targeted and had to be spent precisely on these activities. For this reason, the "savings" from these temporarily inactive activities could not be used even provisionally by the municipality to provide liquidity in meeting the emergency costs of the municipal budget.

- In the local activities, for the period of the state of emergency and the declared emergency epidemiological situation, all cultural institutes of local importance - museums, libraries, galleries, theatres, operas, philharmonics, orchestras and ensembles, cinemas, etc. - have ceased to operate. Many cultural and sports events, local holidays, festivals, etc. with tourist potential were cancelled. The sports sites - stadiums and halls, and the tourist sites have also been closed for more than two months. This would lead to real savings from subsistence expenditures, but not compensate any labour costs. At this stage, however, it is difficult to predict the size of these savings so that municipal councils, which are fully authorized, can allocate the savings when updating the budget. At the next stage, when the detailed analyses of the actual savings have been made, they would serve as a real reserve until the end of the year, provided that the situation has stabilized until then.

\section{REVENUES WHICH MUNICIPALITIES "LOSE" / POSTPONE FOR AN INDEFINITE PERIOD}

The collected own revenues of the municipalities, with which the expenditures for the implementation of local policies are covered, have drastically decreased during the state of emergency compared to the same period in previous years. This is the period when due to the possibility of paying the annual amounts of the real estate tax and vehicle tax, and in most municipalities the municipal waste collection tax as well, taxpayers are given a 5\% discount and the revenues from these taxes are traditionally very high - about $1 / 4$ of the annual revenues.

According to signals from municipalities, the larger ones have reported up to a sevenfold decrease in revenues, and in the others between $6 \%$ and $35 \%$ for this period.

The reasons for the above are: 
1. Revenue "deferred" in time:

- The enforced state of emergency and the restrictive measures imposed to limit the spread of the new coronavirus and the calls for social distancing have sharply reduced the number of taxpayers in the halls of the municipal tax offices. At this time in previous years, it was necessary to open more tax offices to handle the flow of taxpayers, but the measures taken this year to limit contacts significantly hindered and delayed the service of citizens. This led to the recommendation of other ways of paying local taxes - through online payment, bank transfers, cash desks of payment service system operators and others;

The provided legal opportunity to use the $5 \%$ discount for taxpayers who have paid the real estate tax and vehicle tax due by June 30 (instead of April 30), according to the Decree $\S$ 26 of the Law on Measures and Actions during the state of emergency, announced by a decision of the National Assembly of 13 March 2020 (2);

- The introduced measures, rising unemployment and general insecurity and the declining incomes of certain categories of people employed in the sectors most severely affected by the crisis have forced citizens to prioritize the spending of households and businesses in times of crisis, so that in addition to their vital costs and household bills they would pay their obligations to the state first because they will be subdued to more drastic measures in case of delay.

2. "Lost" revenue:

- The measures for social distancing, in fact, have stopped the transactions with property and this has led to a loss of tax on the transactions;

- Suspended visits to municipal facilities (cultural, tourist and sports) - reduced the revenues from ticket sales and rentals of sports facilities to zero;

Failure to hold local festivals in the municipalities - tourist tax; municipal fees; business revenue;

Municipalities with a distinct tourist profile have suffered huge losses because they often own and/or manage cultural, tourist and historical sites on their territory;

- The non-held cultural events of international significance also brought serious losses to the organizing municipalities due to cancelled prepaid trips and contracts;

Guided by their reactivity to the problems of citizens and companies, municipalities have taken a number of measures to support businesses which depend on municipalities. In most municipalities, small businesses not operating during the state of emergency were exempted from paying a monthly rent for municipal property and land during the state of emergency, and in many places it was possible to reduce the rent by a different percentage for the period after it;

After numerous signals from the municipalities for a drastic reduction of the collection of own revenues in the first weeks of the state of emergency, the Management Board of the National Association of Municipalities in the Republic of Bulgaria (NAMRB) decided to conduct a survey among the municipalities on the trends and impact of the COVID-19 crisis on municipal budgets. The survey was conducted in the period April 30-May 11, 2020 , when $82 \%$ of the municipalities or 217 municipalities out of a total of 265 participated in it with information about the implementation of the budget of the respective municipality. The full analysis of the results of the NAMRB survey on the state of municipal budgets in a state of emergency can be downloaded from the NAMRB website (6).

The following trends in the NAMRB study can be highlighted:

$>$ By applying the most popular approach of performance assessment, which is used by the Ministry of Finance - with accumulation since the beginning of the year to a certain date, the percentage of reduction of municipal revenues in the end of March is estimated at $4.5 \%$ decrease (7). Thus, it turns out that the percentage of reduction of owns revenues of the municipalities are not so high as to require special action by the state. According to this approach, the own revenues of the municipalities at the end of February reached a surplus of $16.1 \%$ compared to the previous year and only at the end of April shrank by $25 \%$.

$>$ Receipts from own revenues, calculated on a monthly basis of municipalities for the period March 1 - April 31, 2020 have decreased compared to the same period in the previous year by $41 \%$, whereas tax revenues have collapsed by $45 \%$. This decrease in revenues is almost halved, compared to the reported own revenues for the same two-month period of the previous year, where the large municipalities regional centres are most affected with an average decrease of $44-46 \%$. This highlights the severity of the problem of large municipalities in this situation, with a high dependence on own source revenues, to 
provide liquidity for paying the costs of maintaining the level of public services.

According to the survey, the "losses" of own revenues for the period March-April 2020, compared to the same period of the previous year amount to BGN 159 million, which will lead to a shrinkage of an average of $11 \%$ of the planned annual revenues. By the end of May, NAMRB experts expect that the reduction of own revenues will have reached a total amount of over BGN 200 million.

$>$ Revenues from grants and donations increase significantly, despite their low fiscal contribution to municipal budgets.

$>$ Expenditures on local activities and cofinancing, with the exception of the costs of financing cleanliness activities, are also declining, but at a much slower pace, compared to the decline in own source revenues. Due to the specifics of the current crisis, i.e. the impossibility to directly limit the expenditures at the same rate as the own revenues had shrunk, the municipalities managed to reduce their expenditures by the end of April 2020, compared to the same period in 2019 by only BGN 44 million. The experts do not expect a forced reduction of expenditures for local activities and cofinancing by May, but on the contrary expenditures are projected to increase by over BGN 242 million compared to the same period last year, due to the expected relaxing of social distancing measures which will lead to the opening of non-functioning municipal activities.

$>$ As a whole, the expenses for cleaning activities are increasing, for which in the specified annual plan as of February 2020 an increase of $13 \%$ has been set, compared to 2019, and by the end of April 2020 the funds planned for cleaning will have increased by 2 points up to $15 \%$ compared to the same period last year.

$>$ All municipalities participating in the survey have reported excessive and unforeseen expenses during the state of emergency. The total amount of these excessive and unforeseen expenses in the municipal budgets for the studied period 1.03.2020 - 30.04.2020 is a little over BGN 6 million. About 3\% of them are unpaid. The share of these costs in the total costs for local activities and for co-financing of the activities delegated by the state is $0.3 \%$. The expected amount of funds needed to cover these costs by the end of June 2020 is expected to reach BGN 18 million.
Municipalities at local level exert great efforts to maintain employment in municipal enterprises, companies and activities that for objective reasons have ceased their work, and respectively limited their opportunities to generate revenue. In this difficult period of crisis of unknown duration, municipalities are still capable to guarantee the payment of staff costs, despite the fact that some employees have used paid and unpaid leave during the state of emergency. The employees in local activities and municipal enterprises are over 36 thousand people, whose salaries and insurances are financed from the own revenues of the municipalities. In comparison, the employees in the municipalities comprise over $1 / 3$ of the jobs directly employed in tourism nationally, a sector which will benefit from a number of state support measures. Due to the revenue policy and in order to maintain the achieved employment levels, the staff costs in the precrisis period are higher than the previous year, followed by a gradual decrease. This is due to the actions taken for using paid annual leave and unpaid leave by employees of municipal structures and enterprises, due to the restrictions imposed by the Ministry of Health on the work of certain units and/or due to the drastic decline in the income from fees and services.

In general, in 2020, municipalities have reduced the costs of maintenance, interest, subsidies and investments, at the expense of increasing social costs.

The data show a clear trend of forming a permanent deficit in the municipal budgets as a result of the imposed state of emergency and the relevant restrictions in order to stem the spread of the coronavirus infection, which by the end of May is expected to exceed BGN 77 million. Given the general situation in the country and the slowdown in the economy, the likelihood of overcoming this deficit in the short term (by the end of the year) is minimal.

\section{MEASURES FOR OVERCOMING THE LIQUIDITY CRISIS IN MUNICIPALITIES}

On the basis of the above, several proposals for adopting measures to overcome the liquidity crisis in the municipalities can be made. Those of them that would have a quick direct fiscal effect on the municipal budget by the end of 2020 are:

Providing municipalities with special subsidies to compensate for the decrease in revenues as a 
result of the crisis, for example by increasing the total equalization subsidy for municipalities, distributed according to transparent and objective criteria and indicators;

Providing temporary interest-free loans to municipalities from the central budget to cover current expenses in local activities;

Earlier transfer of the second part of the equalization subsidy for 2020 ;

Transformation of the available transitional balances from unspent target transfers from previous years (2017, 2018 and 2019) and accumulated on the accounts of the municipalities, into a total transfer for local activities.

Financial compensation from the state (based on article 45, paragraph 2 of the Public Finances Act) for the reduction of revenues as a result of the extended terms for using the discount in case of prepayment of the full amount of real estate and vehicle taxes;

Temporary suspension of repayment of loans from municipalities to the central budget, including temporary suspension of imposition and recovery of financial corrections;

extension of the measure 60/40 to municipal enterprises and activities. This will provide support to those employed in municipal enterprises, whose activities have been practically suspended with the declaration of the state of emergency, by extending the scope of the Decree № 55 of the Council of Ministers of 30 March 2020 (8) and adding a similar opportunity for those working in local activities in the field of culture, education, sports, recreation and tourism in the municipalities, including in municipal enterprises;

lifting the moratorium on the sale of agricultural lands under article 19, paragraph 1 of the Act on the Ownership and Use of Agricultural Land, which have attracted the interest of registered farmers. At this stage, due to a legal restriction introduced at the end of 2015 (transitional and final provisions to the Law amending and supplementing the Law on the Protection of Agricultural Lands §14, para 2 ) in force until the end of 2020, these lands are not subject to sale. The eventual lifting of this ban would lead to an increase in own revenues, which would compensate to some extent for the negative impact of the crisis on the collection of local taxes and fees.

The proposals for measures to overcome the liquidity crisis in the municipalities, which have a medium-term or indirect effect on the financial condition of the municipalities, can be structured as follows:

Ongoing work on expanding the own revenue base of the municipalities through shared and/or new tax revenues for the municipalities; resumption of the National Program for Energy Renovation of Multifamily Residential Buildings. In addition to the medium-term effect on increasing employment in the regions, in the long run it will ensure the reduction of energy poverty and prevent the risk of decay of prefabricated concrete buildings and the consequent risk of homelessness of their owners.

Elimination of the obligation of municipalities to pay VAT, or at least the application of reduced rates for some public services such as: waste management, street lighting, repairs of public infrastructure - roads and streets, sewage and water supply, etc.

To legally establish a ban on seizing bank accounts of municipalities for a period of three years after the lifting of the state of emergency; lifting the moratorium on the sale of agricultural lands under article 19, paragraph 1 of the Act on the Ownership and Use of Agricultural Land which have attracted the interest of registered farmers. At this stage, due to a legal restriction introduced at the end of 2015 (9) in force until the end of 2020, these lands are not subject to sale. The eventual lifting of this ban would lead to an increase in own source revenues, which on the one hand would compensate to some extent the negative impact of the crisis on the collection of local taxes and fees, and on the other, through the sale of agricultural lands could provide sustainable employment to households which have remained without income as a result of the crisis.

Revision of the criteria for determining the access to equalization subsidy of the municipalities (realized revenues of 1 person over $120 \%$ of the national average), including targeted support for municipalities that have been deprived of access to this subsidy in 2020 and as a result of the crisis are objectively accumulating arrears.

Stimulating the public investments by creating funds for financing municipal infrastructure. 


\section{CONCLUSION}

The solution to the most significant problem, at this stage, is the provision of liquid funds for the payment of debts, without disturbing the fragile balance between targeted and nontargeted funds in municipal budgets. Some of the above proposals (possibility to use temporary interest-free loans from the central budget to cover local expenditures, which would have a quick short-term fiscal effect to solve the problem, have already been resolved by law. It remains to be seen how many of the municipalities will benefit from them and what the effect on their municipal budgets will be in the coming years.

Based on the analysis of the needs for expenditures in all local activities and the degree of reduction of own revenues, each municipality will make an assessment for updating the municipal budgets for 2020;

The detailed analysis made by NAMRB on the impact of the COVID-19 crisis on the municipal budgets for the period March-April 2020 must be made for the subsequent months. Thus, based on a study of the results of the crisis, the actual losses of municipalities' own revenues will be assessed and a package of compensatory measures and mechanisms will be prepared to minimize the negative effect of the crisis on municipal budgets in the long run.

\section{REFERENCES}

KARATOVA N.

1. https://www.who.int/emergencies/diseases/no vel-coronavirus-2019

2. Decision of the National Assembly of 13.03.2020 for declaring a state of emergency, based on Art. 84, item 12 of the Constitution of the Republic of Bulgaria, Promulgated, SG, iss. 22 from 13.03.2020, in force from 13.03.2020

3. https://stateaid.minfin.bg/bg/page/421 Communication from the European Commission, Temporary Framework for State Aid Measures to Support the Economy in the Conditions of the Current Outbreak of COVID-19

4. https://www.namrb.org/grizata-naobshtchinite

5. Decision of the Council of Ministers № 208 of 16.04.2019 for adoption of standards for activities delegated by the state with natural and value indicators in 2020 .

6. https://www.namrb.org/obshtchinskiteprichodi-sa-namaleli-s-povetche-ot-40-samoza-perioda-mart-april-2020-g

7. https://www.minfin.bg/bg/810

8. CMD № 55 of 30 March 2020 determining the terms and conditions for payment of compensation to employers in order to maintain the employment of employees in an emergency situation.

9. Prehodni i zaklyuchitelni razporedbi kam Zakona za izmenenie I dopalnenie na ZOZZ $\S 14$, al.2 